\title{
The role of principal academic supervision in improving the professionalism of teachers of state junior high schools
}

\author{
Joko Winarno $^{1}$, Happy Fitria ${ }^{2}$, Yessi Fitriani ${ }^{2}$ \\ ${ }^{1}$ Sekolah Menengah Pertama Negeri 2 MuaraTelang, Indonesia \\ ${ }^{2}$ Universitas PGRI Palembang, Indonesia
}

\section{Article Info \\ Article history: \\ Received Jul 23 $3^{\text {th }}, 2021$ \\ Revised Aug $11^{\text {th }}, 2021$ \\ Accepted Aug 30 ${ }^{\text {th }}, 2021$ \\ Keywords: \\ Academic supervision \\ Principal \\ Teacher professional}

\begin{abstract}
This study aims to describe the role of the principal in the implementation of academic supervision, the results and obstacles of academic supervision in improving the professionalism of teachers of SMP Negeri in MuaraTelang, Banyuasin District. This research uses qualitative research with a qualitative descriptive approach. The location of this research is SMP Negeri in MuaraTelangBanyuasin District. Data collection was carried out using observation, interviews and documentation. Data analysis using data reduction techniques, data presentation and drawing conclusions. Checking the validity of the findings is done by observing persistence, triangulation and reference adequacy. The results of this study explain the positive and significant role of principal academic supervision in improving the professionalism of teachers of SMP Negeri in MuaraTelang District, Banyuasin. Through discussion of the implementation of academic supervision, the results of academic supervision, and the inhibiting factors for academic supervision of school principals. The results of the supervision carried out by the principal of the State Junior High School in MuaraTelangBanyuasin District were able to improve teacher professionalism in pedagogic competence, personality competence, professional competence and social competence.
\end{abstract}

(C) 2021 The Authors. Published by IICET.

This is an open access article under the CC BY-NC-SA license

(https://creativecommons.org/licenses/by-nc-sa/4.0

\section{Corresponding Author:}

Winarno, J.,

Sekolah Menengah Pertama Negeri 2 MuaraTelang, Indonesia

Email: jokowinar08@gmail.com,

\section{Introduction}

Schools are formal educational institutions, to carry out all activities of school principals and educators in carrying out their duties. The school also functions as a place to carry out the teaching and learning process that involves the principal, educators and students. The function of the school is not only to provide knowledge to students but to develop teacher work performance in improving the teaching and learning process.

The principal has a big enough role, to foster the ability of teachers in the learning process and improve competence, so that they become professional teachers. The principal as the leader of an educational institution functions as a manager and supervisor, must be able to provide professional services, in order to improve teacher professional competence.

[1] "the principal as the leader of an educational institution, is able to manage, pay attention, supervise, guide the teachers in the teaching and learning process. One of the ways is by supervising the educators on 
duty. Thus affecting, increasing the discipline of educators in the learning process ". [2]"One of the factors that affect teacher performance is coaching by the principal".

The principal must have supervisory competence, this is in accordance with Permendiknas No.13 of 2007, which includes planning an academic supervision program in the context of improving teacher professionalism, through appropriate supervision approaches and techniques. At the time of initial observation, the principal still found educators / teachers who had not prepared learning tools when they wanted to teach in class. For this reason, the principal must pay attention to and carry out supervision of educators in the school he leads. [3]"Supervision is guidance given to all school staff, so that they can improve their ability to develop better teaching and learning situations.

[2]"Academic supervision is a service to help, encourage, guide and foster educators to be able to improve their abilities and skills in carrying out learning tasks. From some opinions of experts, it can be concluded, "Academic supervision is a service or assistance provided by supervisors to educators to improve things in the learning process, so that it can run effectively and efficiently by conducting simulations, coordination and guidance on an ongoing basis.

Teachers are professional educators with the main task of educating, teaching, fostering, guiding, directing, training, assessing and evaluating student learning outcomes. [2] Stating that quality professional teachers are teachers who have the ability to create a learning climate in the classroom, have the ability to manage learning, have the ability to provide feedback and reinforcement and have the ability to improve themselves. Meanwhile, [5] Professional teachers are teachers who have intellectual intelligence, moral intelligence, emotional intelligence, and motor intelligence.

The characteristics of a professional teacher in outline are threefold: 1) A professional teacher must master the field of science that he will teach well. 2) A professional teacher must have the ability to convey or teach his / her knowledge (transfer of knowledge) to his students effectively and efficiently. 3) A professional teacher must adhere to the professional code of ethics. Teachers must have a strong interest in carrying out their duties in accordance with the required professional principles of teachers.

The supervision activities of the principal, in the previous explanation, aim to guide educators to overcome difficulties or obstacles faced by educators in learning. A school principal is in charge of providing guidance and encouragement for educators to carry out improvements and reforms in education and teaching in accordance with the applicable curriculum.

To be able to manage teachers and staff in empowering human resources optimally, principals are required to master managerial competencies. A school principal must also have supervisory competence in order to carry out the supervision program education in order to improve teacher professionalism. The purpose of this study was to analyze and describe the role of principal academic supervision in improving the professionalism of teachers of SMP Negeri in MuaraTelang District.

\section{Method}

This research is a qualitative research with a qualitative descriptive method approach. [6] qualitative research is a research method that is defined as a scientific way to obtain data with specific purposes and uses. [1] qualitative research is a way of obtaining data by understanding the phenomenon of what is experienced by the object of research holistically.The data sources in this study are: 1) Principal of State Junior High School in MuaraTelang District, 2) Teachers from the three State Junior High Schools in MuaraTelang District and the source of data obtained from documents, such as: pictures, photos, notes or writings, archives that are related to the focus of the research. There are two sources of data, namely primary data and secondary data, [7].

This qualitative research uses data collection techniques, as follows: observation, interviews and documentation. The method of observation is carried out by using two ways of participatory observation, namely observers participating in activities and non-participatory observation, namely observers not participating in activities. The interview method is carried out to obtain data or information related to the implementation of academic supervision by the principal. [8]. Documentation, namely collecting non-human data, in the form of evidence, as follows: pictures, photos, writings, sound recordings and so on. Researchers carried out observations, interviews and documentation itself by using research instruments. The data analysis used in this research is inductive data analysis. 


\section{Results and Discussions}

This study aims to analyze the implementation of academic supervision of school principals in an effort to improve the professionalism of teachers of SMP Negeri in MuaraTelangBanyuasin District. Sources of data obtained from informants are as follows: (1) Description of the implementation of educational supervision; (2) Description of the results of educational supervision; (3) Description of the barriers to academic supervision.

The data / results obtained through this study are as follows: (1) Academic supervision is carried out by the principal based on a planning program made with the school's academic supervision team. The implementation of academic supervision at State Junior High Schools in MuaraTelang District is carried out by the principal and the team. To provide guidance, motivation, and assessment in order to improve teacher professionalism, through pre-class visit activities, class visit implementation activities and post-class visit activities.

The academic supervision activities of school principals include: (a) Preparation of academic supervision programs; (b) Preparation of academic supervision instruments; (c) Preparation of schedule for the implementation of academic supervision; (d) Implementation of academic supervision; (e) Preparation of academic supervision reports

(2) The results of the academic supervision of the principal, based on the study of documentation and the results of interviews with the principal and the teacher council of SMP Negeri in MuaraTelang District, that the analysis of data on the results of academic supervision can be seen from the aspects that were supervised, including: mapping content standards, indicator development, syllabus development, preparation of lesson plans, compilation of KKM, learning methods, assessment techniques, analysis of learning outcomes, utilization of ICT and improvement and enrichment programs. Shows that there is a positive and significant increase in the context of realizing an increase in professional teachers. (3) Obstacles in the implementation of academic supervision carried out by the principal of the State Junior High School in MuaraTelang District, among others, are caused by: limited time available, the schedule of supervision activities often concurrently with other activities or tasks. Such as: official meetings, workshops and other activities at the sub-district, district and provincial levels, and also an obstacle to the background of subject teachers who are not in accordance with their respective disciplines.

[9] Supervision means providing services or assistance to improve the quality of teacher teaching in the classroom, which in turn improves the quality of learning of students, as well as to develop quality teaching and learning situations to improve professional teachers. The role of the supervisor, namely the principal in carrying out academic supervision, must avoid actions that are instructing or patronizing, but by acting in a partnership approach, namely serving, supporting, helping, dividing work tasks to all educational components. [10] Supervisors play a role in encouraging teachers to apply their abilities in carrying out teaching assignments, developing personal skills (skills), having serious attention (commitment) to their duties and responsibilities, so as to foster teacher work motivation, to create and improve professional teachers.

Guided by the concepts, principles and techniques of supervision, the role of the principal. Regarding the complex tasks of teachers, an academic supervision approach is needed that is able to direct and solve problems in the learning process.Efforts to improve the quality of learning outcomes, which are related to the implementation of teaching and learning activities in class management starting from preliminary activities, core activities, closing activities and evaluation of learning and follow-up of the principal as supervisor, can plan supervision programs related to teacher administration as follows: annual program, semester program, syllabus, lesson plans, educational calendar, face-to-face schedule, list of values, KKM (minimum completeness criteria), and student attendance.

The principal in carrying out academic supervision always involves the vice principal and senior teachers who are members of the academic supervision support team, so that it can run well and smoothly, by compiling a supervision program and disseminating it to the teacher council. Academic supervision activities at SMP NegeriMuaraTelang District, based on observations and observations, have been going well and smoothly. The teachers welcome the implementation of academic supervision by the principal or the academic supervision assistant team with a friendly and family-like attitude. This can indicate that there is a positive and significant role that academic supervision carried out by the principal is able to improve teacher professionalism.

\section{Conclusions}

Based on the results of research and discussion of the role of principal academic supervision in improving the professionalism of teachers of state junior high schools in MuaraTelang, Banyuasin, it can be concluded as 
follows: (1) Implementation of principal academic supervision at SMP NegeriMuaraTelang District, there is already a positive rol based on the aspects of the completeness of the syllabus documents, the preparation of RPP instruments (Prota, Promes, RPP), the compilation of KKM documents is declared complete; (2) The results of the principal's academic supervision on the aspects of mapping content standards, developing indicators, learning methods, use of learning resources, use of learning media, assessment techniques, analysis of learning outcomes are declared complete, while the use of ICT, analysis of learning completeness is declared incomplete, there is a need for improvement. . This is due to limited school infrastructure and teachers who teach subjects not in accordance with their scientific discipline. Academic supervision activities must be carried out continuously and gradually in order to improve teacher professionalism and school quality; (3) The inhibiting factor for academic supervision is the limited time, schedules that coincide with other activities: official meetings, workshops, or other activities, the principal has difficulty supervising teachers who are not in accordance with their educational background.

Based on the research, the suggestions given to several parties are as follows: (1) The implementation of academic supervision should be in accordance with an appropriate supervision schedule, so that teachers are more enthusiastic in preparing completeness. (2) After being supervised, it is expected that there will be an evaluation and follow-up, as a material for improving future supervision.

\section{References}

Mulyasa.E. 2006. Becoming the Principal of a Professional School. Bandung: PT. Youth RosdaKarya Supardi. Teacher Performance. Jakarta: PT. Raja GrafindoPersada, 2014.

Subroto, Suryo. Educational Management in Schools. Jakarta: RinekaCipta, 2010.

Mulyasa.E. Teacher Competency Test and Performance Assessment. Bandung: PT RemajaRosdaKarya, 2013. Asmani, Jamal Ma'mur. Effective Tips School Education Supervision.Yogyakarta: DIVA Press, 2012.

Sugiono. Educational Research Methods: Quantitative, Qualitative and R \& D Approaches. Bandung: Alfabeta. 2010.

Arikunto, Suharsini. The basics Supervision. Jakarta: RinekaCipta, 2010

Kristiawan, M. Yuniarsih, Y. \&Fitria H.2019. Bandung Education Supervision: Alfabeta.

Sah Understanding, Piet A. Basic Concepts and Techniques for Educational Supervision. Jakarta: RinekaCipta, 2000.

Rivai. M and Pure. 2009. EducationManagement/Analysis of Theory and Practice. Jakarta. Rajawali Pers 